\title{
Discussion of cathodoluminescence of Recent biogenic carbonates: an environmental and ontogenetic fingerprint
}

G. M. Friedman comments: Barbin et al. (1991) state 'most authors consider recent primary biogenic carbonates to be non-luminescent.' They quote several authors who have made such negative statements, but they do not reference studies that have demonstrated the usefulness of cathodoluminescence in the study of modern biogenic carbonates that make up reefs. Barbin et al. (1991) are not alone in questioning the uselessness of cathodoluminescence in modern biogenic carbonates as expressed in the work of their predecessors. Most recently Major (1991) likewise commented 'cathodoluminescence in carbonates is primarily a result of diagenesis', especially 'postdepositional precipitation or recrystallization'.

The purpose of this discussion is to explain the usefulness of cathodoluminescence in the study of modern biogenic carbonates in reefs, as developed by Hill in 1976 and Friedman (1985). The reason why these studies have not been quoted are (a) Hill's (1976) study has remained an unpublished Master's of Science thesis (C. M. Hill, unpub. Master's thesis, Renneselaer Polytechnic Institute) and (b) Friedman's (1985) paper was published under a title which does not include the word cathodoluminescence and was concerned with problems of carbonate classification rather than using luminescence as a tool.

Blasting open a coral reef or drilling through such a reef rarely displays framework-building organisms in growth positions. Biting and boring and rasping or mechanical breakdown convert solid colonies of calcium carbonate skeletons secreted by the reef organisms into an everincreasing supply of skeletal particles that accumulate within the reef or in the vicinity of the reef. Boreholes through modern reefs reveal mostly debris; framework builders in a position of growth are sporadic or even absent. Both skeletal particles and interparticle cement in reefs consist of high-magnesium calcite and aragonite. High-magnesium calcite commonly luminesces, whereas aragonite does not luminesce and appears black under an electron beam. Three kinds of submarine cryptocrystalline cement occur in reefs. These are: (1) cements that luminesce brightly, (2) cements that luminesce dimly or faintly, and (3) cements that do not luminesce at all. Under plane-polarized light or crossed nicols these three kinds of cement appear identical. In places, a cement 'stratigraphy' can be demonstrated where two kinds of cement appear in sharp lateral stratigraphic contact, one luminescent and the other non-luminescent (Friedman, 1985, figs 1E, F). These differences in behaviour under an electron beam relate to differences in the concentration of activator $\left(\mathrm{Mn}^{2+}\right)$ ions. Because the geochemical characteristics of manganese are similar to those of magnesium, manganese replaces magnesium in the highmagnesium calcite lattice in sufficient concentration to produce luminescence. The sharp boundaries between the three kinds of cement indicate variations in concentration of $\mathrm{Mn}^{2+}$ ions and different times and/or rates of precipitation. The same principle of bright luminescence to non-lu- minescence applies to skeletal particles, especially those of coralline algae.

In many reef samples the bulk of the skeletal particles are composed of aragonite which does not luminescence. By contrast the high-magnesium calcite cement shows strong luminescence. In such samples a particle-cement ratio can be measured under an electron beam.

Under cathodoluminescence modern Red Sea reefs luminesce more than Pleistocene reefs. Pleistocene reef samples are weakly or non-luminescent. The reason for decreased luminescence is the diagenetic change from luminescent high-magnesium calcite to less luminescent lowmagnesium calcite. The presence of $\mathrm{Fe}^{2+}$ ions in lowmagnesium calcite restricts luminescence. This observation is at variance with the experience of others who claim that diagenetic processes result in cathodoluminescence (Major, 1991).

The colour plates of Barbin et al. (1991) showing cathodoluminescence and transmitted light photomicrographs are most instructive. They should be compared with those previously published (see Friedman, 1985).

V. Barbin, K. Ramseyer, J. P. Debenay, E. Schein, M. Roux $\&$ D. Decrouez reply: The discussion by Friedman and the quoted paper (Friedman, 1985) stresses the cathodoluminescence $(\mathrm{CL})$ characteristics of cryptocrystalline eogenetic high-magnesium calcite and aragonite cement and only briefly mentioned CL of unaltered biogenic skeletal particles, which was the aim of our paper.

Our studies on biogenic carbonates (Barbin et al. 1991; Barbin, 1992) revealed clearly that the mode of carbonate precipitation, i.e. biomineralization versus crystallization from a pore fluid, are two different processes with regard to trace element incorporation into carbonate minerals. Statements true for one process may therefore not necessarily be identical for the other mode of crystallization.

A good example for this difference in Friedman's claim that eogenetic high-magnesium calcites commonly luminesce. In recent crinoids and echinoids we generally observed only a faint blue-green luminescence (if any at all). Also the assertion that aragonite does not luminesce may be true for eogenetic cements, but is not necessarily true for biogenic particles. As early as 1972, Sommer described yellow-green luminescing aragonitic shells and we also show this phenomenon in our paper (see for example Fig. 2, parts Ib, $2 \mathrm{~b}$ and $3 \mathrm{~b}$ in Barbin et al. 1991). Barbin (1992) also showed luminescent growth bands in different species of Nautilus. In addition, the aragonitic skeletons of corals generally exhibit a weak blue luminescence which can be difficult to detect beside strongly luminescing particles.

We thank Friedman for his comments, but do not feel that they in any way alter the main conclusions, which were to show (1) that recent biogenic carbonate skeletons often luminesce, (2) that luminescence in bioclasts is not always a fingerprint for diagenetic alterations, and (3) that $\mathrm{CL}$ of 
modern animal skeletons may be used to unravel environmental conditions during the life of the animal.

\section{References}

BARBIN, V. 1992. Fluctuation in shell composition in Nautilus (Cephalopoda, Mollusca): evidence from cathodoluminescence. Lethaia 25, 391-400.

Barbin, V., Ramseyer, K., Debenay, J. P., Schein, E., Roux, M.\& DeCrouez, D. 1991. Cathodoluminescence of Recent biogenic carbonates: an environmental and ontogenic fingerprint. Geological Magazine 128, 19-26.
FrIedman, G. M. 1985. The problem of submarine cement in classifying reefrock: an experience in frustration. In Carbonate Cements (eds N. S. Schneidermann and P. M. Harris), pp. 117-21. Tulsa: SEPM, special publication no. 36.

Major, R. P. 1991. Cathodoluminescence in Post-Miocene Carbonates: Luminescence Microscopy and Spectroscopy. In Qualitative and Quantitative Applications (eds C. E. Barker, H. Y. Colburn and C. Kopp), pp. 149-53. SEPM Short Course no. 25, 198 pp.

Sommer, S. E. 1972. Cathodoluminescence of carbonates, 2. Geological applications. Chemical Geology 9, 275-84.

GERALD M. FRIEDman, Department of Geology, Brooklyn College and Graduate School of the City University of New York, Brooklyn, NY 11210, U.S.A. and The Northeastern Science Foundation, Rensselaer Center of Applied Geology, 15 Third Street, P.O. Box 746, Troy, NY 12181-0746, U.S.A.

V. BARBIN, E. SCHEIN \& M. ROUX, Laboratoire des Sciences de la Terre, Université de Reims, B.P. 347, F-51062 Reims Cedex, France.

K. RAMSEYER, Geologisches Institut, Universität Bern, Baltzerstrasse 1, CH-3012 Bern, Switzerland.

J. P. DEBENAY, Laboratoire de Géologie, Université d'Angers, Boulevard Lavoisier, Belle-Beille, F-49045 Angers Cedex, France.

D. DeCrouez, Muséum d'Histoire Naturelle, 1 route de Malagnou, C.P. 434, CH-1211 Genève 6, Switzerland. 